\title{
Study of motion sickness incidence in ship motion
}

- Nguyen Anh Tuan ${ }^{2}$

- Tat-Hien Le 1,2 $^{1,2}$

${ }^{1}$ National Key Laboratory of Digital Control and System Engineering (DCSELAB), HCMUT, VNU-HCM

${ }^{2}$ Dept. Naval Architecture \& Marine System Engineering, Ho Chi Minh city University of Technology, VNU-HCM

(Manuscript Received on July 13 ${ }^{\text {th }}, 2015$; Manuscript Revised October 16 $6^{\text {th }}, 2015$ )

\section{ABSTRACT}

Motion sickness incidence index (MSI) is one of essential issues in ship motion research to access the comfort of passenger on board cruises and yachts. In the paper, wave energy spectrum and MSI will be analyzed. Evaluation will not only provide an initial feedback of passenger's comfort in ship design stage but also estimate the suitable speed to steer the cruise comfortably.

Key words: MSI, motion sickness incidence, passenger cruise, wave energy spectrum.

\section{INTRODUCTION}

Nowadays, many prominent yacht builders research and apply the anti-rolling devices such as Beneteau, Azimut and Ferretti [1]. The cost of anti-rolling device installment contributes 10\% of the cost of the luxury yacht like Azimut Flybridge $50 \mathrm{ft}$ [2]. Recently, ship motion has been an essential topic in yacht design [3].
To comprehend the advantages of ship motion research, one of well-known luxury yachts, Azimut Flybridge 54 in figure 1, the roll motion is reduced up to $80 \%$ after installing antirolling device. Hence, the comfort of passengers and yacht owners plays the essential role in order to increase awareness of competition.

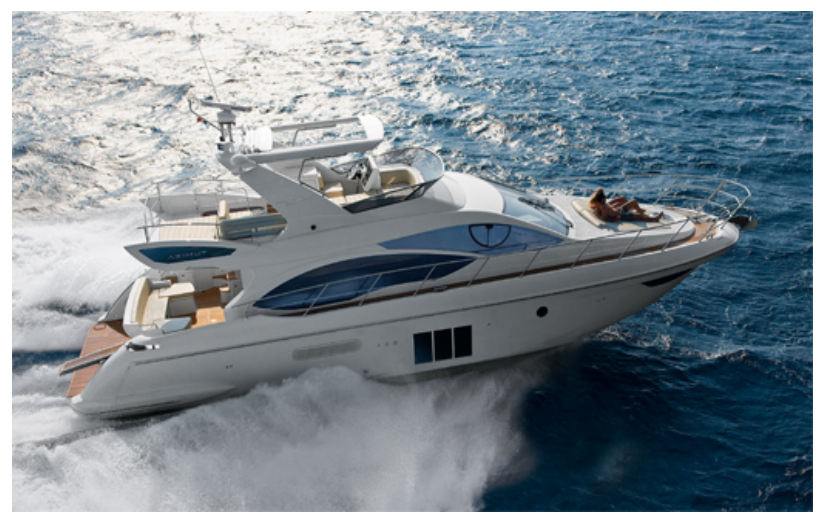

Figure 1. Anti-rolling device installed on Azimut Flybridge 53 reduces rolling motion up to 80\% [4]

\section{Trang 102}




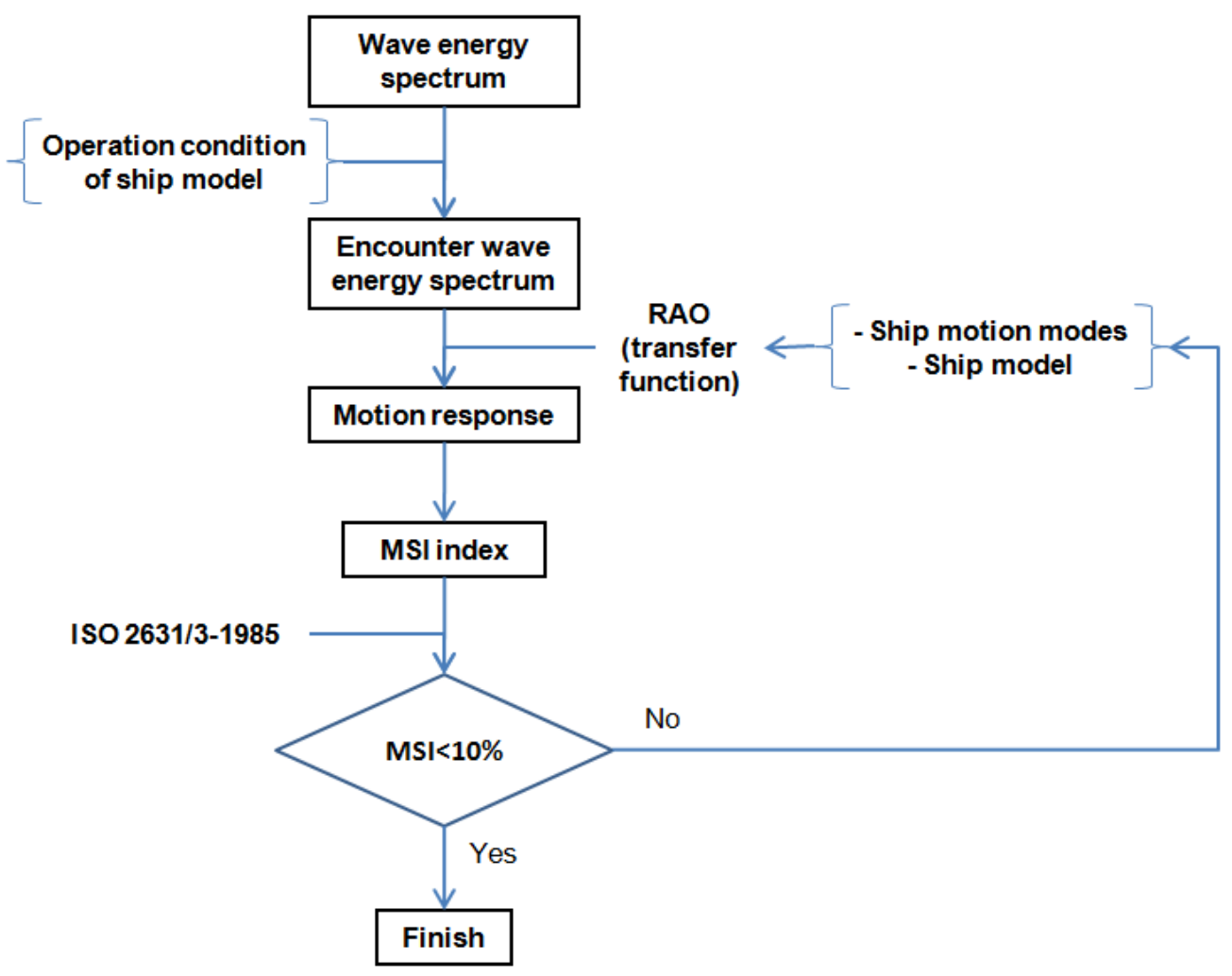

Figure 2. The proposed process of the comfort assessment

Our research focuses on a comfort of motion sickness incidence (MSI) of small passenger boats and yachts by following ISO 2631/3-1985. In addition, the well-known wave spectrum including Bretschneider spectrum and JONSWAP spectrum are applied to calculate the characteristics of the motion response spectrum. The analysis process of motion sickness incidence (MSI) calculation will be described briefly in the figure 2 .

\section{The process of the comfort assessment}

First step, after collecting the characteristic of the wave including the observed circular frequency, the average period and the significant wave height, the wave energy spectrum is performed. Then, the characteristic of the ship operation condition including the ship course direction and velocity of ship are imported to calculate and to plot the encounter wave energy spectrum.
Next step, one computes response amplitude operators (RAO) by using the uncouple roll motion model and the characteristics of vessel, especially transverse metacentric height and roll gyradius. After that, the motion response spectrum will be estimated based on RAO.

Final step, motion sickness incidence index is computed according to ISO 2631/3-1985 to evaluate the comfort of passengers on board.

\subsection{The encounter wave energy spectrum}

Two models of wave energy spectrum such as Bretschneider spectrum and JONWAPS (Joint North Sea Wave Project) spectrum are used.

Bretschneider spectrum use two parameters that are the characteristic wave height $\overline{\mathrm{H}}[\mathrm{m}]$ and the average period $\overline{\mathbf{T}}[\mathrm{s}]$. Bretschneider wave spectrum is suitable for open sea areas with long crest [1]. Bretschneider wave spectrum $\boldsymbol{S}_{\boldsymbol{\zeta}}(\boldsymbol{\omega})$ $\left[\mathrm{m}^{2} . \mathrm{s}\right]$ is described as follows: 
$\mathrm{S}_{\zeta}(\omega)=172.75 \frac{\overline{\mathrm{H}}^{2}}{\overline{\mathrm{T}}^{4}} \omega^{-5} \exp \left(-\frac{691}{\overline{\mathrm{T}}^{4}} \omega^{-4}\right)$

The JONSWAP spectrum with the peakedness factor $\gamma=3.3$ in the paper will be described as follows [2] [1]:

$$
\begin{aligned}
& S_{\text {JONSWAP }}(\omega) \\
& =0.658 \cdot 172.75 \frac{\bar{H}^{2}}{\bar{T}^{4}} \omega^{-5} \exp \left(-\frac{691}{\bar{T}^{4}} \omega^{-4}\right) \\
& \cdot C(\omega) \\
& \quad \text { where }
\end{aligned}
$$

$$
\begin{gathered}
C(\omega)=\gamma^{\exp \left(-\frac{1}{2 \sigma^{2}}\left(\frac{\omega}{\omega_{0}}-1\right)^{2}\right.} \\
\omega: \text { the circular wave frequency }\left[\frac{\mathrm{rad}}{\mathrm{s}}\right]
\end{gathered}
$$$$
\sigma: \text { the step function }
$$

$$
\begin{gathered}
\sigma=0.07 \text { for } \omega<\omega_{0} \\
\sigma=0.09 \text { for } \omega>\omega_{0}
\end{gathered}
$$

Circular frequency at spectral peak

$$
\omega_{0}=\frac{4.849}{\bar{T}}
$$

JONSWAP spectrum comprises Brestchneider spectrum. Figure 3 shows the difference between JONSWAP and Bretschneider spectrum, the statistic data in Aegean Sea are calculated as a case study [3] .

The encounter wave energy spectrum

When yacht moves on wave, the angle between yacht direction and wave travel is named encountering angle $\boldsymbol{\mu}$ (Figure 4).

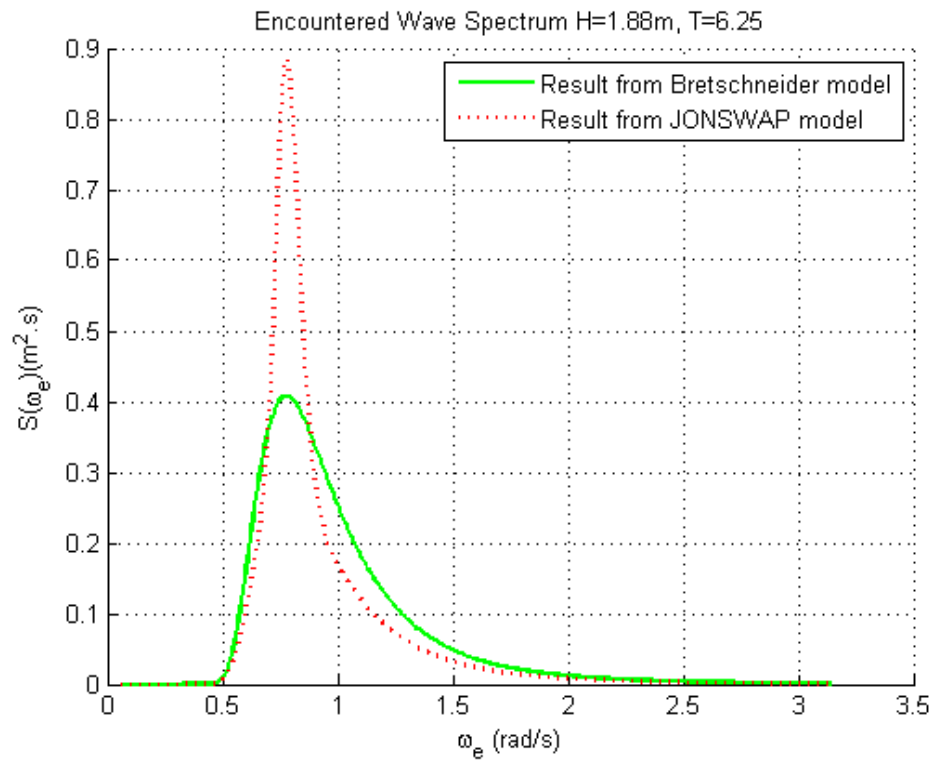

Figure 3. The encounter wave energy spectrum were plotted based on Bretschneider and JONSWAP model 


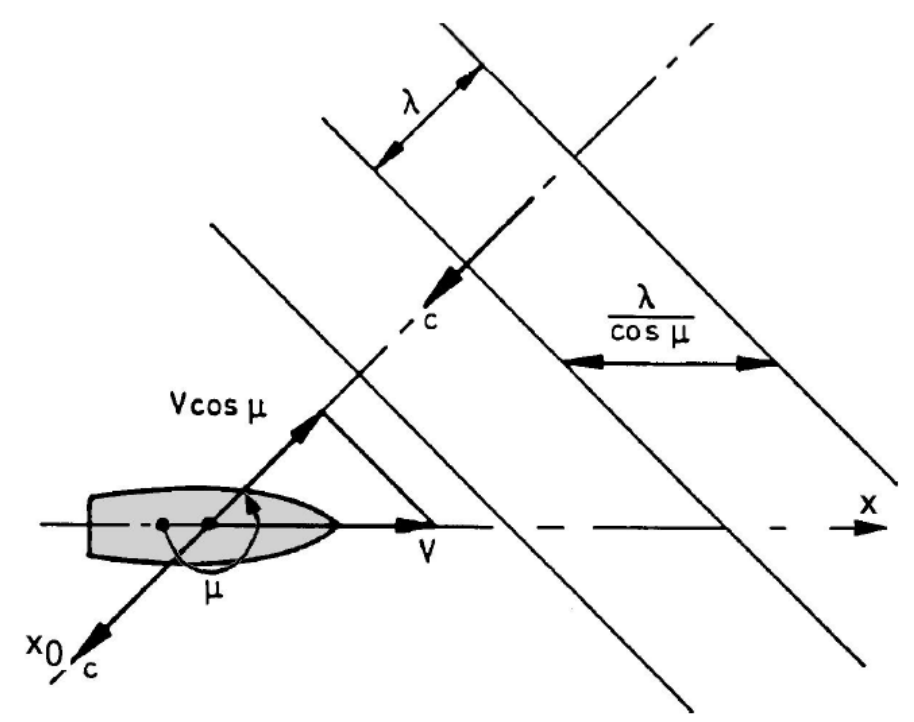

Figure 4. The encountering angle $\boldsymbol{\mu}$ [1]

The encounter frequency describes as follows [4]:

$$
\omega_{e}=\omega\left(1-\frac{\omega V}{g} \cos \mu\right)
$$

where:

$\mathrm{V}$ : ship speed, [m/s];

$\mathrm{g}$ : gravity acceleration, [m/s2];

$\boldsymbol{\omega}$ : Wave frequency, [rad/s];

$\boldsymbol{\mu}$ :The encountering angle [deg], beam wave condition at $\boldsymbol{\mu}=90 \mathrm{deg}$, a heading wave condition at $\boldsymbol{\mu}=180 \mathrm{deg}$.

Using the wave energy spectrum $\boldsymbol{S}(\boldsymbol{\omega})$ and the encounter frequency to calculate the encounter wave energy spectrum $\boldsymbol{S}\left(\boldsymbol{\omega}_{e}\right)$ [4]:

$S\left(\omega_{e}\right)=\frac{S(\omega)}{\left|1-\frac{2 \omega V}{g} \cos \mu\right|}$

\subsection{Uncoupled roll motion model}

The standard model of uncoupled roll motion in regular wave is the second order differential equation: [2]

$$
\begin{aligned}
\left(\mathrm{I}_{4}+\mathrm{A}_{44}\right) \ddot{\eta}+\mathrm{B}_{44} \dot{\eta}+\mathrm{C}_{44} \eta \\
=\mathrm{F}_{4}\left(\cos \omega_{\mathrm{e}} \mathrm{t}\right. \\
\left.+\mathrm{i} \sin \omega_{\mathrm{e}} \mathrm{t}\right)
\end{aligned}
$$

where: [kg.m2] ;

I4: Mass inertia of roll motion, $\mathbf{I}_{\mathbf{4}}=\mathbf{k}_{\mathbf{x x}}^{2} \boldsymbol{\nabla} \boldsymbol{\rho}$,

$\mathrm{k}_{\mathrm{xx}}$ : Gyradius of yacht about the $\mathrm{x}$-axis through the center of gravity $\mathrm{CG},[\mathrm{m}]$;

$\nabla$ : Displacement volume of yacht, [m3];

$\rho$ : Density of sea water, $1025 \mathrm{~kg} / \mathrm{m} 3$;

A44: Added inertia coefficient of roll motion, $\mathrm{A}_{44}=0.3 \mathrm{I}_{4}$, [5];

$\mathbf{C}_{\mathbf{4 4}}$ : Hydrostastic restoring coefficient of roll motion, $\mathrm{C}_{44}=\mathrm{GM}_{\mathrm{t}} \cdot \nabla \cdot \rho \cdot \mathrm{g}$;

$\mathrm{GM}_{\mathrm{t}}$ : Transverse metacenter height, [m].

Response amplitude operator (RAO) in the roll motion describes as the below equation:

$$
\mathrm{RAO}_{\text {roll }}=\frac{1}{\sqrt{\left(1-\lambda^{2}\right)^{2}+4 \beta_{44}^{2} \lambda^{2}}}
$$

where:

Tuning factor:

$$
\lambda=\frac{\omega_{e}}{\omega_{0}}
$$


Natural frequency of uncoupled roll motion $\omega_{0}[\mathrm{rad} / \mathrm{s}]$ :

$$
\omega_{0}=\sqrt{\frac{\mathrm{C}_{44}}{\mathrm{I}_{4}+\mathrm{A}_{44}}}
$$

\subsection{Ship motion response and the criteria of} the comfort of passengers

Ship motion is strongly effected by the encounter wave energy from wave travel and excitation forces through RAO [4]. The below equation describes the ship motion response of roll motion [2]:

$$
S_{\text {zRoll }}\left(\omega_{e}\right)=R A O_{\text {roll }}^{2} S_{\zeta}\left(\omega_{e}\right)
$$

The root mean square (RMS) of the 2nd order spectral moment of roll motion response spectrum $\mathrm{m}_{2}$ is the root mean square acceleration $\mathrm{v}_{\text {zRMS }}\left[\mathrm{m} / \mathrm{s}^{0.5}\right],[2]$ :

$$
\begin{aligned}
v_{z R M S} & =\sqrt{m_{2}}= \\
& \sqrt{\int_{\min \left(\omega_{e}\right)}^{\max \left(\omega_{e}\right)} \omega_{e}^{2} \cdot S_{\text {ZRoll }}\left(\omega_{e}\right) \cdot d \omega_{e}}
\end{aligned}
$$

The root mean square (RMS) of the 4th order spectral moment of roll motion response spectrum $\mathrm{m}_{4}$ is the root mean square acceleration $\mathrm{a}_{\mathrm{zRMS}}[\mathrm{m} / \mathrm{s} 1.5]:[2]$

$$
\begin{aligned}
& a_{z R M S}=\sqrt{m_{4}} \\
& =\sqrt{\int_{\min \left(\omega_{e}\right)}^{\max \left(\omega_{e}\right)} \omega_{e}^{4} \cdot S_{z R o l l}\left(\omega_{e}\right) \cdot d \omega_{e}}
\end{aligned}
$$

In 1974, O'Hanlon and McCauley represented firstly the concept "Motion sickness incidence" []]. Obeying ISO 2631/3-1985, MSI value has to be smaller than $10 \%$ in 2 hours exposure time [7]. According to Lloyd (1998)
MSI after 2 hours exposure described as below expression [5]:

$$
\begin{aligned}
M S I[\%]=100 \cdot & \left.\Phi \frac{\log _{10}\left(\frac{\left|\ddot{S}_{3}\right|}{g}\right)-\mu_{M S I}}{0.4}\right\} \\
& <10 \%
\end{aligned}
$$

where:

$\ddot{\mathbf{s}}_{3}$ : the heave acceleration, $\ddot{\mathbf{s}}_{3}=$ $0.798 \sqrt{\mathrm{m}_{4}}[\mathrm{~m} / \mathrm{s} 2]$;

$\boldsymbol{\Phi}(\mathbf{x})$ :the standard normal cumulative distribution function with zero mean and unity standard deviation.

O'Hanlon and McCauley (1974) suggested the factor $\boldsymbol{\mu}_{\boldsymbol{M S I}}$ based on the encounter frequency fe as the below expression []]:

$\mu_{M S I}$

$=0.654+3.697 \log _{10} f_{e}$

$+2.32\left(\log _{10} f_{e}\right)^{2}$

\section{Case study}

The specification of the model of vessel and ship operation conditions in case study describes as follows (Figure 6):

- Waterline length LWL $=6.9 \mathrm{~m}$;

- Maximum beam $\mathrm{B}=2.1 \mathrm{~m}$;

- Draft T = $0.4 \mathrm{~m}$;

- Displacement volume $\boldsymbol{\nabla}=2.545 \mathrm{~m}^{3}$;

-Transverse metacenter height $\mathrm{GMt}=1.453 \mathrm{~m}$;

- Gyradius of roll motion $\mathrm{k}_{\mathrm{xx}}=0.923 \mathrm{~m}$;

- Damping factor of 0.05 is suggested by Lewis (1989) [9]

- Beam wave condition, $\mu=90 \mathrm{deg}$

- Operation speed V = 10 knot

\section{Trang 106}



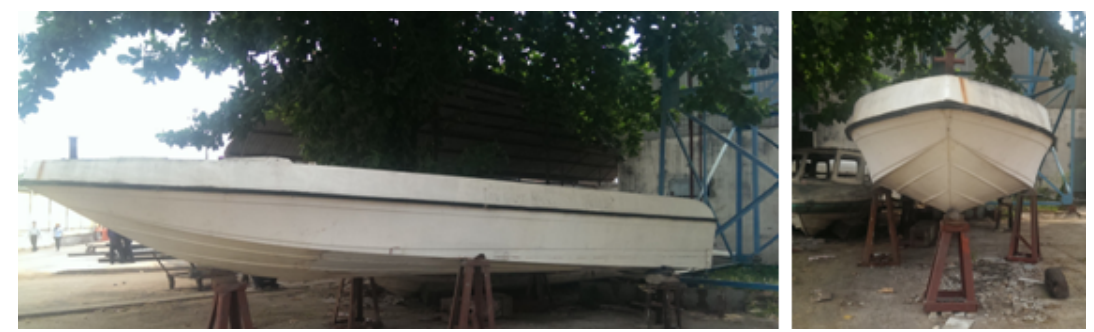

Figure 6. Small passenger ship

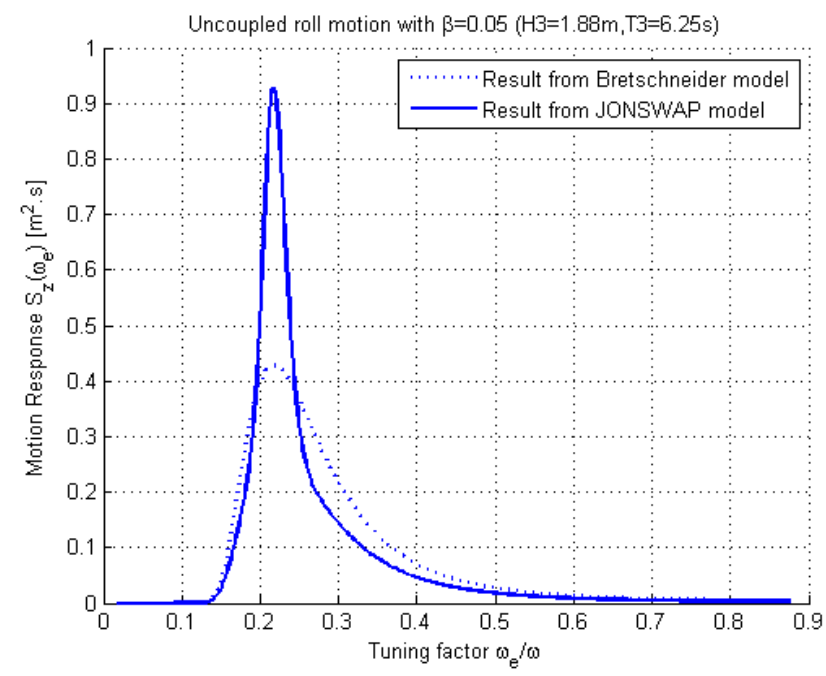

Figure 7. Ship motion response is calculated at Sea State 4 in Aegean Sea (the characteristics wave height $1.88 \mathrm{~m}$ and the average period $6.25 \mathrm{~s}$ ) [3]

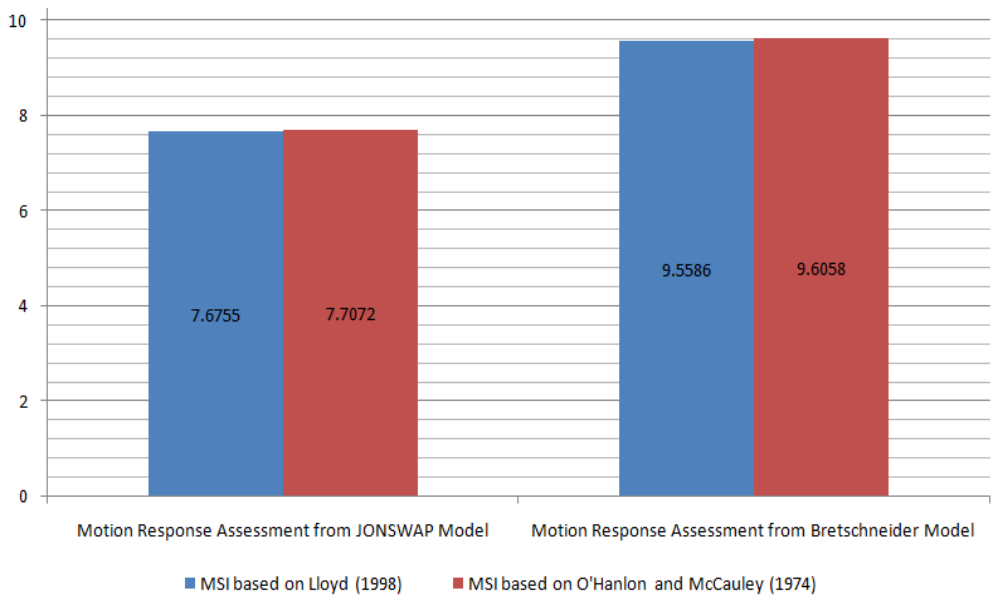

Figure 8. Result of MSI [\%] in case study 
Figure 7 indicates that ship motion response based on JONSWAP model is narrower and higher than Bretschneider model. Moreover, roll motion response of JONSWAP model decreases faster than roll motion response of Bretschneider model.

In 2014, the research of EU-7FP project FAROS conducted by Finland and UK suggests using the criteria of ISO 2631/3-1985 of $10 \%$ to assess the comfort of passengers in exposure time up to 2 hours [7]. In case, MSI exceeds $10 \%$, ship owner should recognize the solution of antirolling device installment.

After calculating MSI of case study, results in figure 8 represents the comfort of passenger do not exceed the criteria of ISO 2631/3-1985 of $10 \%$ in two cases using Lloyd's expression (1998) or using O'Hanlon. In addition, it is said that under $10 \%$ of passengers on board does not suffer any vomit and seasickness.

\section{CONCLUSIONS}

In the paper, we offer the progess of assessment of the comfort based on JONSWAP and Bretschneider models. After calculating MSI, ship designer or yacht owner can decide to alter the weight distribution including ballast tank, sewage tank and fuel tank in initial stage or consider anti-rolling device installment. Besides that, captain can consider the suitable velocity to make passengers on board feel comfortable.

On the other hand, the research also supports undergraduate students to comprehend difficult subjects including wave energy spectrum , response amplitude operation, and MSI in ship motion.

Acknowledgements: This research is supported by National Key Laboratory of Digital Control and System Engineering (DCSELAB), HCMUT, VNU-HCM under grant number 281/2014/HD-SKHCN.

\section{Nghiên cứu chỉ số gây say sóng MSI trong chuyển động tàu}

- Nguyễn Anh Tuấn ${ }^{2}$

- Lê Tất Hiển ${ }^{1,2}$

${ }^{1}$ Phòng thí nghiệm trọng điểm quốc gia về kiểm soát kỹ thuật số và Kỹ thuật Hệ thống (DCSELAB), HCMUT, ĐHQG-HCM

${ }^{2}$ Bộ môn KT Tàu thủy, Khoa KT Giao thông, Trường ĐH Bách khoa, ĐHQG-HCM

\section{TÓM TÁT}

Chỉ số gây say sóng MSI là một trong những vấn đề quan trọng được nghiên cứu trong chuyển động tàu để đánh giá sụ̣ thoải mái của hành khách trên tàu và trên du thuyền. Trong bài báo này, chương trình tính toán MSI sẽ được xây dựng dựa trên các phổ năng lượng sóng đã được công nhận. Nghiên cứu không chỉ giúp nhà thiết kế tàu đánh giá ban đầu về sự thoải mái của hành khách trong giai đoạn thiết kế, mà còn giúp ước lượng tốc độ phù hợp để điều khiển tàu hạn chế say sóng cho hành khách.

Từ khóa: MSI, say sóng, tàu khách, phổ năng lượng sóng

\section{Trang 108}




\section{REFERENCES}

[1]. J.M.J. Journée and Jakob Pinkster, Introduction in ship hydrodynamics.: Delft University of Technology, 2002.

[2]. Maxsurf Motions Manual.: Bentley System Inc., 2013.

[3]. J.H. Erikson, "Common Procedures for Seakeeping in the Ship Design process," STANAG 41542000.

[4]. Rameswar Bhattacharyya, Dynamics of Marine Vehicles. USA: John Wiley \& Sons, Inc., 1978.

[5]. A.R.J.M. Lloyd, Seakeeping: Ship behaviour in rough weather: Ellis Horwood Limited, 1998.

[6]. Tuan Anh Nguyen and Hien Tat Le, "Study of the effects of roll motion on transverse stability of a small boat,"
International Journal of Mechanical Engineering and Application, vol. 3, no. Transportation Engineering Technology, pp. 24-28, 2015.

[7]. Seppo Kivimaa et al., "Ship motions, vibration and noise influence on crew performance and well-being studies in FAROS project," in Transport Research Arena, Paris, 2014.

[8]. O'Hanlon J.F. and McCauley M.E., "Motion sickness incidence as a function of the frequency and acceleration of vertical sinusoidal motion," Aerospace Medicine, vol. 45, pp. 366-369, 1974.

[9]. E.V. Lewis, Ed., Principles of Naval Architecture: The Society of Naval Architects and Marine Engineers, 1989. 